\title{
Historical urban tourism: Developmental challenges in Johannesburg 1920-1950
}

\begin{abstract}
Over the past decade there has been considerable growth and maturation of research concerning contemporary urban tourism. Tourism in major cities is not a new phenomenon rather it has existed from the earliest times of civilization following the birth of cities. The historical development of cities as tourist destinations has remained little investigated as urban tourism research is overwhelmingly 'present-minded'. This paper addresses the neglect of historical studies in urban tourism. Using archival sources an investigation is undertaken of the early development of tourism in Johannesburg, South Africa's largest city, which evolved from a gold mining camp established in 1886. The analysis focuses on the period from 1920 when the first tourism promotional activities were initiated to 1950 when national government enacted the Group Areas Act which began the radical reshaping of tourism in South Africa under the influence of apartheid legislation. In the formative years of urban tourism in Johannesburg between 1920 and 1950 two key overarching challenges are identified. These are the challenges of identifying and promoting the city's tourism assets and of the building of a competitive infrastructure for tourism development, most notably in terms of the hotel accommodation sector.
\end{abstract}

Keywords: urban tourism, historical urban tourism, tourism infrastructure, Johannesburg, South Africa

\section{Introduction}

The nexus of tourism and history is well-established, albeit sometimes contested in tourism scholarship (Towner \& Wall, 1991; Towner, 1995; Walton, 2005a, 2005b; Cirer-Costa, 2012). Among others Timothy (2012: 157) reminds us that people "have undertaken travel away from home for millennia as they mobilised from villages and tribal units to hunt, trade and explore" and that "historical accounts highlight the ancient Egyptians and Romans travelling for pleasure and sightseeing to the far corners of their empires". In a seminal article Towner and Wall (1991: 73) review the potential for the further development of historical approaches in tourism studies reflecting that this potential "has yet to be realized". Over 20 years ago Walton (1997: 564) re-issued the challenge that scholars should take the history of tourism 'seriously' and argued that the "burgeoning field of tourism studies has remained essentially presentminded". In a further critical commentary Walton (2005a: 3) maintains "tourism studies should pay serious attention to the relevance of historical research and writing to its concerns". CirerCosta (2012) re-affirms the value of historical analysis in tourism scholarship. For tourism research there are multiple reasons that it needs an historical awareness "not least to inform the ways in which tourism itself tries to use history, through the marking, marketing and exploitation of traces, stories, heritage, authenticity, and, ultimately distinctiveness" (Walton 2005b: 115). In another more recent contribution Walton (2009) undertook a survey of tourism's history and concludes positively that there was now a remarkable amount of activity but with research neglect of certain geographical regions, most notably Africa. For geographers, one of the major disciplinary contributors to tourism scholarship, it was stressed that the historical dimension of tourism development and planning "cries out" for further exploration and analysis (Saarinen et al. 2017: 312). 
The underdevelopment of historical studies in tourism literature is particularly evident in terms of urban tourism writings. Until the 1980s the volume of scholarly writings on urban tourism was limited. Nevertheless, as shown by Pasquinelli (2015) there has been a substantial international upturn in interest on urban tourism research. This awakening of research is inseparable from the impact of deindustrialization on the economies of North America and European cities and correspondingly of tourism's important role in 'reinventing' them as postFordist urban centres (Law, 1992, 1993). Several reviews have appeared on the expanding literature and maturation of research concerning urban tourism; collectively, these emphasize a range of research themes which are under academic scrutiny (Ashworth \& Page, 2011; Pasquinelli, 2015; Coca-Stefaniak et al., 2016; Pasquinelli \& Bellini, 2017; Rogerson \& Rogerson, 2017). Arguably, the dominant focus of most literature on urban tourism "has been on contemporary developments in urban tourism rather than its history" (Bickford-Smith, 2009: 1765). Indeed, it is stressed by Saarinen et al. (2017: 311) that "amidst a swelling and rich body of international writings around geographies of urban tourism, planning and development, mainstream debate is almost entirely concentrated upon present-day developments around tourism in cities which bypasses any substantive concern for past or inherited geographies of city tourism".

Tourism in major cities is not a new phenomenon rather it has existed from the earliest times of civilization following the birth of cities (Cohen \& Cohen, 2015). Nevertheless, the historical development of cities as tourist destinations has remained little investigated as urban tourism research remains overwhelmingly 'present-minded'. The most notable contribution is, perhaps, the work of Cocks (2001) on the rise of urban tourism in American cities at the turn of the $20^{\text {th }}$ century. Other exceptions include two South African studies. Bickford-Smith (2009: 1765) examines how different tourism sites and particular tourism gazes were constructed in Cape Town, South Africa's iconic destination for international travel, and situates "contemporary developments in urban tourism within a historical analysis of the place-selling of this city from the late $19^{\text {th }}$ century onwards". Focused on the apartheid era Rogerson $(2016,2017)$ records the implementation and struggles against the racial segregation of beaches across South Africa's major coastal leisure destinations. Building upon these foundations the aim in this paper is to address further the oversight of historical studies in urban tourism research. Using an array of archival sources an investigation is undertaken of the early development of tourism in Johannesburg, South Africa's largest city, which evolved from a gold mining camp established in 1886. Sources include material accessed from variously the national archives depot (Pretoria); the historical papers collections held both at Johannesburg Public Library (Harold Strange Collection) and the University of the Witwatersrand (William Cullen Historical Papers); tourism business directories, industry press and local newspapers; and, material extracted from the collection of the South African Railways and Harbours (hereafter $\mathrm{SAR} \& \mathrm{H})$.

The analysis centres on the period from 1920 when the first notable tourism promotional activities were initiated for South Africa as a whole and began to impact on the growing city of Johannesburg. The closing date of 1950 is a landmark year in South African urban history for it marked the enactment by national government of the Group Areas Act which (together with the Reservation of Separate Amenities Act of 1953) began the radical reshaping of tourism in South Africa under the influence of apartheid legislation. It will be shown that during the formative years of tourism in Johannesburg between 1920 and 1950 a number of constraints upon tourism expansion can be recognised. 


\section{Early tourism promotion of South Africa}

An understanding of Johannesburg's emergence as a tourism destination is inseparable from the broad contours of initial tourism expansion and promotion for South Africa as a whole (Norval, 1936; Saunders \& Barben, 2007). According to Bickford-Smith (2009: 1767) the growth in the country of "a substantial tourism market, as elsewhere in the world, accompanied the transport revolution associated with railways and steamships". During the late $19^{\text {th }}$ century the development of faster, larger and more luxurious steamships as well as the expansion of railways into South Africa's interior, including links between Cape Town and Johannesburg, were significant for facilitating tourist travel to and around South Africa. The Union of South Africa came into existence only in 1910. Pirie (2011: 74) argues that concerted promotion of international tourism to South Africa began soon thereafter when the newly established government-owned SAR\&H "created a Publicity and Travel Department". The promotional activities of SAR\&H are seen by van Eeden (2011: 602) as one of "the key moments in tourism" for South Africa. Early discussions around international tourism promotion took place in 1911 aimed at "advertising South Africa as a tourist resort" (SAR\&H, 1920a: 8). Following this, in 1914 funds were voted of an amount of $£ 25000$ as an initial contribution towards enhancing awareness of the country to potential visitors from Great Britain, USA, Europe and (later) Australia. For the SAR\&H the core purpose of its advertising campaign was to generate additional commercial traffic, increasing rail network use with the aim "to supplement domestic holiday traffic by enticing summer holidaymakers away from coastal resorts" (Pirie, 2011: 75). The timing of the advertising campaign was inauspicious, however, and with the outbreak of World War 1 these activities ceased; it was only with the restoration of peace in 1919 that the scheme was revived.

In its implementation as the Oversea Advertising Scheme from 1919-20 emphasis was upon making South Africa's attractions known not only for tourists but also now for potential settlers and investors. Foster (2003) stresses that the role and activities of the SAR\&H were critical for building the modern South African nation as the organisation emerges as the state's "sole agency for promoting tourism, settlement and investment". It was argued that conditions had changed since 1914 and that with a greater knowledge of the resources of South Africa it is "desirable to consider the possibility of broadening the oversea advertising scheme to take cognisance of, not only the travel attractions, but the farming, manufacturing, mining and usually general industrial possibilities of the Union" (SAR\&H, 1919: 1). The linkages of SAR\&H tourism publicity to encourage white settlement in the country represents a continuous thread throughout the 1920s and into the 1930s. Alongside the distribution of an official handbook of South Africa and pamphlets related to farming and industry, the publicity campaign included the production of touring booklets targeted to "attract tourists to South Africa" (SAR\&H, 1920b: 1). It was made clear that tourism was seen as significant for the operations of SAR\&H. Indeed, it was stated that "much paine (sic) has been taken, in writing up, photographing and bioscoping the country, to bring out adequately the historic, scenic, climatic and general travel attractions"(SAR\&H, 1919: 2). During 1921 the SAR\&H commissioned a pamphlet aimed at "attracting the English-speaking middle class tourists" (Wolf, 1991: 104). This covered the main cities, the Cape Peninsula, Victoria Falls and 'the Natives' (Zachariah, 1921). The campaign focus was to present "the broad impressionistic picture of the Union interests sufficiently to induce visitors from oversea" (SAR\&H, 1920a: 9). Much emphasis was given to "the untouched and primitive attractions" to be enjoyed of South Africa which could be experienced in conditions of modern comfort (Wolf, 1991: 105). 
Overall, Pirie (2011: 73) maintains that SAR\&H was the "arch promoter of overseas tourism" to South Africa for almost 30 years after Union in 1910. Equally, for both Foster (2003) and van Eeden (2014) the activities of SAR\&H assumed a strategic role in nurturing the early development of tourism in South Africa. The practices of SAR\&H transformed the possibilities for tourism as railways "not only brought distant places into the national economy, they also made it possible for citizens to travel and visit those places" (Foster, 2003: 664). In addition, as van Eeden (2011: 602) points out, prior to the advent of mass air travel "all travellers to and from South Africa had to pass through either the harbour in Cape Town or Park Railway Station in Johannesburg".

\section{Johannesburg as an incipient tourism destination}

SAR\&H marketing was vital in shaping the emerging tourism landscape of South Africa (Foster, 2003; van Eeden, 2014). Nevertheless, despite the enormous volume of advertising and pamphlets issued by SAR\&H, complaints were raised by many South African towns that in its selection of visual imagery certain potential tourism destinations were given prominence by SAR\&H advertising "whilst others are scarcely mentioned" for international travellers (SAR\&H, 1927). The growing commercial and industrial centre of Johannesburg, which was anchored upon the wealth of gold, was perhaps, not surprisingly one of those less prominent destinations for overseas tourists. During the 1920s groups of American cruiseship passengers arriving from Cape Town visited Johannesburg as part of their tourism itinerary often en route either to Victoria Falls or Lourenco Marques (Pirie, 2011). Although the city's gold mines garnered some attention it was considered by many "that Johannesburg was too similar to American cities to keep the tourist interested" (Wolf, 1991: 109). Other international visitors to Johannesburg during the 1920 s, however, were impressed more especially as the city's image outside South Africa was unpromising. For example, accompanying the HRH Prince of Wales on his visit to South Africa, in 1925 Ward Price (1927: 7) wrote:

.... millions of people throughout the British Empire undoubtedly visualise Johannesburg as erroneously as I did. The picture which that name had always raised before my eyes was of a glaringly new city, laid out in rectangular monotony on a flat and dusty plain. Its outward appearance I expected to be characterized by opulence aggressive to the verge of vulgarity... The inhabitants of this imaginary city of the commonplace I had supposed would be a hard-faced soulless lot with minds centred solely on money-making... As for the lighter side of the city's life, except for a sordid 'new-rich' sort of gaiety, I foresaw none of the cultured amenities or the broad outlook on life that exists in older centres of civilisation. Ward Price (1927: 7)

These images and preconceptions of Johannesburg were overturned by his sojourn in the city from which he sees Johannesburg as a holiday centre with potential.

My first twenty-four hours in the real Johannesburg was enough to make every one of these expectations seem like the figments of a fantastic dream. Nothing could be more different from the impressions which I came with than those with which I go away... Instead of a city without a soul. I have found reproduced here that indefinable but unmistakable metropolitan atmosphere which, in my experience at least, I have never felt so strongly anywhere else but the world's great capitals...Excellent shops; attractive entertainments; surroundings of great natural variety, embellished by villas of quite unusual quality of design, standing in gardens that are models of skill and taste in exploiting the physical beauty of the site - these are circumstances which, if Johannesburg could be transported bodily, would make her one of the show cities of Europe or America. (Ward Price, 1927: 7)

Early promotional advertising produced in 1924 marketed Johannesburg mainly to investors or settlers as 'the commercial heart of South Africa' and the 'Empire's great gold centre' with the 'biggest mines and equipment in the Universe, now or ever'! But, its potential for tourism 
was not overlooked as visitors were encouraged to travel 'to Johannesburg for health, business and enjoyment' with the city described as the 'most interesting place in a country of fascinations'. Particular mention was given to the city's large show grounds which at Easter was the venue for a week long 'pastoral, agricultural, industrial and implement exhibition'. The 1924 Illustrated Guide to South Africa projected the city's attractions for domestic visitors as follows:

Johannesburg, the city of gold, the hub of South Africa, is modern in all that it attempts, and there is no more enjoyable and interesting way of spending a week or month than to visit the Rand and explore the Reef in that period of the year when summer is merging into winter. The atmosphere of the Rand, despite the mining operations that are proceeding even in the pulsating heart of the city, is so pure and rarified that it acts as a tonic to those coming from the coast belt, and it is remarkable, considering the many and diversified attractions that it possesses, that Johannesburg has not organized a gala or holiday season and specially laid itself out to cater for the enjoyment of visitors. (The Union Publishing Agency, 1924: 149)

Further acknowledgement of the city's tourism potential occurred in 1925 with the establishment of the Johannesburg Publicity Association. This organisation was founded to serve as 'the 'guide, philosopher and friend' of everyone, whether correspondent or visitor, business man or tourist, who needs reliable information concerning the Golden City" (City of Johannesburg, 1951: 49). With its trained staff and a bureau situated in the city's downtown, the "traveller is cared for, made to feel welcome, assisted along the way and introduced to the business or professional contacts he desires to make; his tastes and wishes are studied, his time is turned to the best account and there is no need for him to wander aimlessly around Johannesburg"(City of Johannesburg, 1951: 49). One of the major challenges facing the Johannesburg Publicity Association was to counter the widespread images of the city as "some half developed mining town"; instead it "set itself the necessary task of exhibiting a truer picture of the city" (Municipal Magazine, 1927, February: 5). In this respect a vital task for the association was to isolate the city's unique tourism assets and to begin marketing them to visitors.

\section{Defining Johannesburg's tourism assets}

In 1931 and 1933 the Johannesburg Publicity Association worked with the publicity department of the SAR\&H to produce two widely circulated booklets which intended to introduce the city and its attractions to tourists (Johannesburg Publicity Association, 1931; South African Railways and Harbours, 1933). 'Á sunshine city built on gold' was the theme of the first booklet produced in 1931 (Johannesburg Publicity Association, 1931). As the hub of the world's greatest goldfield, it asserted boldly that "Johannesburg is perhaps the chief attraction of Southern Africa" (Johannesburg Publicity Association, 1933: 7). Moreover, Johannesburg "through its very youth is structurally modern" was styled as "a miracle of empire" (Johannesburg Publicity Association, 1933: 3). The pamphlet was aimed at potential investors, settlers as well as tourists and catalogued the city's residential attractions, social clubs, educational centres and, above all, its climatic advantages of "abundant sunshine, pure and exhilarating air" (Johannesburg Publicity Association, 1933: 24). The city's public buildings and parks were highlighted and said to "give mute though solid testimony to the march of progress of this metropolis of South Africa" (Johannesburg Publicity Association, 1931: 3). Among the civic buildings the following were noted as of special interest: Johannesburg City Hall and within it the city hall organ; the law courts, the public library and geological museum, the city art gallery and the Union Observatory where on Wednesday evenings visitors could enjoy "some of the wonders of the heavens through the 'Reunert' 
Telescope, a 9-inch refractor" (Johannesburg Publicity Association, 1931: 20). Much attention was given also to Johannesburg as South Africa's pre-eminent sporting centre, to the important horse races hosted by the Johannesburg Turf Club, and to Ellis Park as the permanent venue of the National Lawn Tennis Championships. Finally, the options were applauded of 'going round and about' Johannesburg to enjoy 'delightful drives' by tram or private motor car through the city's avenues and expanding suburbs to visit the Zoological Gardens, various parks as well as to "a fine rifle range the 'Bisley' of South Africa" (Johannesburg Publicity Association, 1931: 33). The 1933 booklet affirms the roles of Johannesburg variously "as the metropolitan city of Southern Africa, the largest European City in Africa", "the seat of the greatest gold-mining industry in the world" and now "the pivot of the South African transportation system by rail, road and air"(Johannesburg Publicity Association, 1933: 3 and 5). It assured potential visitors that "all the amenities of modern civilisation are to be found in Johannesburg"; in addition to its public buildings and municipal market hall attention is given to its entertainment economy - theatre cinema and music "the most elaborate in South Africa" featuring "names famous in Europe and America" with "the latest releases from oversea studios" (Johannesburg Publicity Association, 1933: 11). Recommendations for leisure and recreation include the city-council organised weekend picnic tours by motor omnibus to a range of lake resorts close to the city as well as slightly further to accessible river and stream resorts (Johannesburg Publicity Association, 1933: 13).

Throughout the 1930s the expanding city of Johannesburg experienced a steady growth of tourists for business, visits to friends and relatives, and for leisure. In terms of leisure travel the SAR\&H viewed Johannesburg as the country's major national source market; since the 1920s it had introduced a system of regular excursion fares and special trains to transport 'inland' residents to popular coastal centres, most importantly Durban, Cape Town, East London and Port Elizabeth. In 1935, however, the Johannesburg Publicity Association criticised the SAR\&H excursion policy for the 'inequality' of facilities granted for travel opportunities to inland as opposed to coastal destinations. The complaint was lodged that as there were "some 192 excursion days being given from inland to coast as contrasted with only 69 excursion days from coast to inland" that the SAR\&H was failing "to popularise general travel by rail by means of a serious, sustained effort for the encouragement of travel to the inland parts of the Union" especially to Johannesburg (Johannesburg Publicity Association, 1935: 7). The SAR\&H argued in response the limited demand for its coast to inland excursion offerings. The most popular times for domestic travel to Johannesburg were at Christmas and at Easter, the latter to coincide with the week-long agricultural show and exhibition. Visitor flows were boosted for special events in Johannesburg such as the 1936 Empire Exhibition held to celebrate the city's golden jubilee (Rand Daily Mail, 15 September 1936). The Empire Exhibition gave a considerable boost to international tourist travel to Johannesburg with further growth continuing in 1937 and 1938 according to reports of the Johannesburg Publicity Association. The expansion of tourism was credited to both favourable conditions overseas as well as to the work of the association in making Johannesburg a touring and vacation centre (Rand Daily Mail, 7 October 1938). It was considered Johannesburg was "at last becoming tourism conscious" with many improvements occurring that enhanced the city's visitor appeal.

The Art Gallery (now being extended), the magnificent Africana Museum, the Public Library, the Rand Airport, the view sites at de Korte Street and Primrose Terrace, the development of wide arterial and link roads, the introduction of modern omnibus services, the seasonal programmes of music, the development of "the Wilds" off Kloof Road and of scenic drives such as the Sylvia Pass, the improvement of the Zoological Gardens, and most generous expenditure on facilities for sport and recreation were civic enterprises which contributed much to the interest and enjoyment of visitors". (Rand Daily Mail, 7 October 1938) 
Advertisements sponsored by the Johannesburg Publicity Association appearing in 1938 underscore the growing tourism awareness of the association as they demonstrate multiple reasons to visit the city (Figure 1). By 1939 it was reported by hoteliers that each month between 1500 and 2000 business visitors or international tourists came to Johannesburg and that the benefit of tourism to the city, albeit not easy to determine, "might well be over $£ 1,000,000$ a year"(Rand Daily Mail, 19 July 1939).

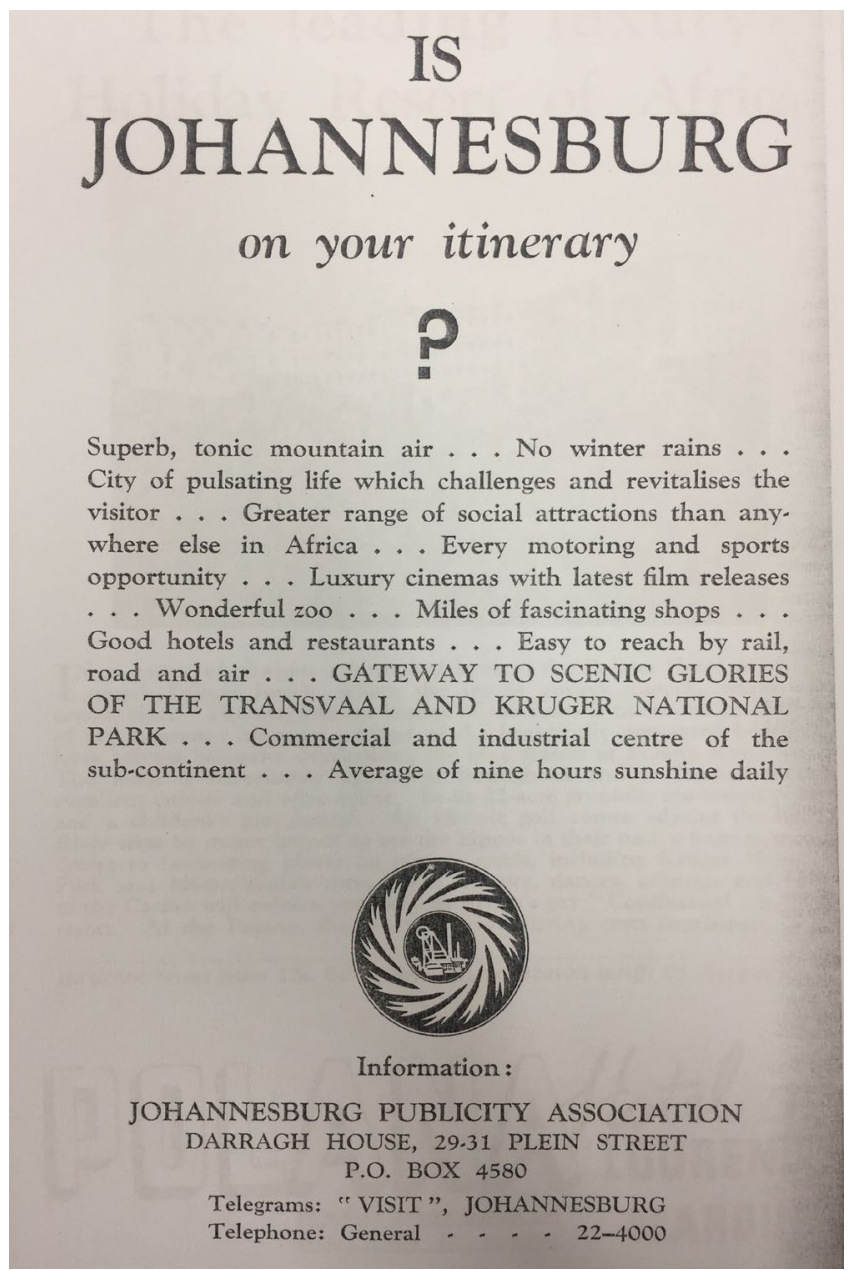

Figure 1: Place Marketing for Johannesburg in 1938 (Source: South African Railways and Harbours, 1938).

The outbreak of hostilities in Europe during 1939 markedly changed the macro-environment for tourism development in South Africa as a whole, and for Johannesburg in particular. World War II disrupted the flows of international tourists to the country from Europe as well as South Africans travelling overseas. Nevertheless, the wartime disruptions of travel from Africa to Europe also opened up new opportunities for South Africa to benefit from the diversion of tourist flows from colonial territories in Central and East Africa (Cape Times, 22 Nov. 1939; Rand Daily Mail, 17 February 1940). In colonial settler territories extended leave for periods of three to six months was granted every three or four years for people to go to a temperate climate for 'recuperation' (Rand Daily Mail, 10 October 1940). In normal circumstances these European residents of colonies such as Belgian Congo, Uganda or Tanganyika would travel to Europe but with war conditions large flows of these regional tourists chose South Africa (Rand Daily Mail, 28 June 1940). Travel to South Africa was overland for most of these European settlers such that in 1940 it was reported that "the texture of incoming visitors has changed", including for Johannesburg (Rand Daily Mail, 10 October 1940). The Johannesburg Publicity Association issued pamphlets and special advise to assist visitors from the Belgian Congo (The 
Star, 12 December 1939). In 1940 it was reported that there had been "a substantially increased number of visitors to Johannesburg" from colonial African territories to which the local publicity association now paid special attention (Rand Daily Mail, 2 Nov. 1940). In 1942 Johannesburg recorded more international visitors than in any year since the 1936 Empire Exhibition.

Even after the 1945 close of hostilities in Europe, South Africa saw further opportunities for continued tourism expansion because of shortages and continued rationing in Europe (Cape Times, 21 Nov. 1945). The Johannesburg Publicity Association (1945: 2) issued a special pamphlet to call for extended marketing of South Africa arguing that "there are few if any activities which offer such promise of handsome returns to costs of promotion as the tourist industry". The post-war activities of the Association continued with support for the production of a number of handbooks and guides for visitors to the city. These continued to recommend visits to the city's "fine collection" of European paintings in the Art Gallery, to the Public Library, Africana Museum, the Observatory, city parks (including Zoo), geological museum, City Hall, conducted tours of underground and surface workings of gold mines, day trips to lake resorts, and to view the city from its highest building, Escom House, described as "an outstanding landmark in the City" (Johannesburg Publicity Association, 1949: 10). The city's night-time economy was deemed special for its "blaze of coloured lights spelling out a multitude of messages and attractions" and in particular its "palatial cinemas" and the annual opera season in March-April (Johannesburg Publicity Association, 1948). For both domestic and international visitors the advantages of Johannesburg tourism at Easter were highlighted to coincide with the Rand Agricultural Show and several sporting events (especially tennis) which were "organized to synchronize with the show" (Johannesburg Publicity Association, 1948) Of note is the opportunity now advertised to visit one of the 50 diamond cutting establishments in Johannesburg and encouragement to go to Northcliff, described as South Africa's 'premier inland pleasure resort' (Johannesburg Publicity Association, 1949: 15).

No visit to Johannesburg is complete without a day spent at Northcliff, from whose commanding heights a 60mile-arc panorama of the central Transvaal - city, reef, mountain and veld - is unfolded... Northcliff is open to visitors daily, with a luncheon, dinner and light refreshment service within its elegant plastic walls, and the delightful garden terraces or direct to your car in the spacious parking area. On Sunday afternoons from 3 to 5.15 o'çlock the Northcliff All Star Band provides orchestral music, including vocal items - and your favourite tunes on request. Dancing Wednesday, Friday, Saturday and Sunday evenings. (Johannesburg Publicity Association, 1949: 15)

Finally, with a clear eye on the entertainment of tourists to the city from Europe or USA there was the considerable promotion of the spectacle of 'tribal' or 'native dancing'. This was likened to experiencing "the very soul of aboriginal Africa" and assuring that "the spectacle of these native 'warriors', prancing, leaping, shouting and singing to the accompaniment of strange music from primitive 'kaffir pianos' is one which rarely fails to make a vivid impression upon the onlooker" (Johannesburg Publicity Association, 1948). The 1947 visitor handbook reflected as follows:

The native mine worker is a most picturesque human type in the great gold mining industry of Johannesburg. While the more advanced of his tribesmen may play association football in teams called "Eleven Experienced", "Winter Swallows", or "Moonlight Stars" which may be matched against such awesome opponents as "Hungry Lions", "Crocodiles", "Dangerous Darkies" or "Naughty Boys" it is often the native mine labourer who clings to his age-old customs of his forefathers and spends his leisure hours in true tribal fashion by participating in a war dance. (Johannesburg Publicity Association, 1947: 25) 
The terminology of 'war dance' was, however, corrected in subsequent publicity material. In the 1949 handbook it was stressed that such dances often represented adaptations of the original village dances "which would be graced by the presence of women and children who would provide the music and singing for the dancers" (Johannesburg Publicity Association, 1949: 14).

In an important caveat it was argued that despite popular opinion "none of the dances are war dances, and in South Africa, few, if any, have a secondary significance beyond the clear and immediate appeal of the rhythmic performance in perfect co-ordination of action" (Johannesburg Publicity Association, 1949: 14). By 1950, two years into the rule of the apartheid government, the spectacle of native dances held at mine compounds on Sunday mornings was described as akin to "folk dances" and, characterised now, for the most part, as simply "the natural expression of high spirits in traditional rhythmic movements". (City of Johannesburg, 1951: 136)

\section{Developing critical infrastructure for urban tourism}

Arguably, throughout the study period of 1920 to 1950, considerable progress was made in terms of establishing certain critical infrastructure to support tourism growth in Johannesburg. In particular, accessibility of the city was greatly enhanced by several advances made in transportation infrastructure.

Foremost was, perhaps, the improvement which occurred in automobility. Until 1923 when the Ford Motor Company was established in South Africa, followed by General Motors in 1926, car ownership was a luxury and only from the mid-1920s did cars become affordable by the middle-class (Van Eeden, 2012). By the 1930s, as Pirie (2013: 75) points out, the railways "no longer monopolized overland tourism". Nevertheless, an essential requirement for improved automobility was a network of navigable roads. In this respect South Africa was challenged as for many years national government had invested considerably in SAR\&H as an efficient long distance transport medium (Foster, 2003). Van Eeden (2012) argues that roads were considered to be only for short distances and the responsibility of the four provinces rather than of national government; as late as the 1920s all weather roads extended only $60 \mathrm{kms}$ beyond Johannesburg, South Africa's economic centre. During the 1930s a set of national roads to link the country's main urban centres was proposed in part to address the needs of overseas tourists (Floor, 1985). Domestic self-drive tourists also benefitted from such infrastructural improvements. Indeed, the bituminisation of the national roads enhanced accessibility to Johannesburg from throughout the country and thereby contributed to the expansion of all forms of city tourism, including business, leisure and VFR travel. Further strengthening tourism in the city was the considerable improvements done to roads within the city. One national tourism guidebook in 1932 commended Johannesburg "as a holiday centre" in particular for those in search of "pleasure, motoring on good roads" (South African Railways and Harbours, 1932: 85).

By 1938 marketing for Johannesburg could applaud the ease of access to the city both by road as well as rail (South African Railways and Harbours, 1938). In addition, already by 1935 Johannesburg assumed the role as the most significant centre in South Africa's air network. The first regular commercial air service by the private company, Union Airways, commenced operations in 1929 based from Port Elizabeth. In 1931 permission was given to SAR\&H to operate a separate department for the transport of passengers and in 1934 they assumed control of Union Airways. With the birth of South African Airways services in 1934, Johannesburg become the hub for domestic air and (subsequently international) travel for South Africa. By 1938 there were daily services operating between Johannesburg and Durban and four flights per week between Johannesburg and Cape Town (South African Railways and Harbours, 1950). The first non-stop services between Johannesburg and Cape Town commenced in 1946. 
International flights from Johannesburg to London began in a partnership of South African Airways with British Overseas Airways Corporation in 1945; the Skymaster service could transport travellers from Johannesburg to London in a total elapsed time of 40 hours. Between 1945 and 1950 a gradual extension occurred in the network of serviced international destinations from Johannesburg, including by 1950 flights to Israel with stops in Nairobi and Khartoum (South African Railways and Harbours, 1950). Until the opening in April 1952 of the international standard Jan Smuts Airport flight operations took place from interim or temporary airport facilities at Palmietfontein (South African Railways and Harbours, 1945).

The major shortcoming for Johannesburg as an incipient tourism destination between 1920 and 1950 relates to the generally unsatisfactory state of the city's accommodation services, and especially of the hotel industry. In many respects the state of the Johannesburg's hotel sector was a mirror of the broader problems experienced concerning the hotel industry in South Africa as a whole. The 1920s promotional advertising by SAR\&H targeted at potential American or European visitors suggested that the allure of South Africa as a destination included that tourists might enjoy 'the primitive' in absolute comfort because of the country's standards of accommodation. Visitors were assured that hotel accommodations in cities were "first class... with up to date sanitation and lighted by electricity" (Wolf, 1991: 105). This said, in terms of expanding international tourism traffic to South Africa as early as 1925 it was recognised that the country needed to have "decent hotel accommodation" but that "from Cape Point to Rhodesia there was room for improvement" (Rand Daily Mail, 12 February 1925). During 1925 it was recommended that the South African Publicity Association be responsible for developing a process of registration for approved hotels which "should bear a distinctive mark, an enamel plate" as a sign of its recommendation to visitors" (Kroonstad Times, 10 February 1925). No such process moved forward, not least because it might threaten the vested interests of the leading liquor companies that were dominating and shaping the hotel sector.

In 1928 landmark legislation was enacted which subordinated the hotel industry to the traffic in liquor (Norval 1936). In terms of what Walker (1977: 9) describes as this 'ill-considered' Act the licensees of existing bars in urban areas were required to provide a minimum of 10 bedrooms to have a liquor licence. Overall, it was clear that "the conditions that the licensees had to meet were largely physical, with little regard being given to the service aspect, and all new licensees carried the obligation to build an 'hotel' (Walker, 1977: 9). As argued elsewhere the consequence was the inevitable further takeover of the hotel industry by the major alcohol companies, especially brewing enterprises (Rogerson, 2011). Essentially, the 1928 legislation created a basic change in the character of South African hotels with the accent on liquor-selling rather than the provision of accommodation services, a situation that prevailed at least until the mid-1960s (Rogerson, 2013a). In return for financial support from the alcohol sector there occurred the acceleration of the hotel industry towards liquor provision and sales with scant concern for accommodation issues. In common with the situation nationally a substantial share of Johannesburg hotels by the 1930s "are in reality nothing but bars" (Norval, 1936: 250). Overall, during the mid-1930s "the relative backwardness" of Johannesburg hotels was apparent (Norval, 1936: 227). Indeed, it was recorded that the largest number of the city's hotel stock "have been in existence for the past 30 to 40 years without any substantial alteration being made to the buildings" (Norval, 1936: 249). With growing flows of international tourism in the 1930s and into the post-war period the degraded state of the accommodation sector became a matter of deepening national concern. In 1943 the Report of the National Hotel Investigative Committee concluded that whilst there had been certain recent improvements in the standards of accommodation offered in South Africa, no grounds existed for complacency and that the "hotels in South Africa were far from being ideal" (Rand Daily Mail, 1 Mar. 1944). 
Indeed, it reflected that there were "far too many complaints" in particular from overseas visitors (Rand Daily Mail, 1 Mar. 1944).

The concerns about hotel standards spanned a range of issues including management, accommodation, service, food and hygiene (University of Cape Town, 1949; Crocker, 1950). In terms of management it was complained that proprietors were not 'experts' and many seemed more interested in the bar trade than issues of accommodation or food services. One observer commented that "so many South African hotels do not take their job seriously" (Gibbs, 1949: 17). Unsurprisingly, therefore, it was argued that the hotel-keeper often was regarded "as a suspicious and even predatory character" (Rand Daily Mail, 27 October 1944). With respect to accommodation, criticisms were directed at shortages of single rooms, private bathrooms, lavatories and of private rooms with suites. Hotel lounges were seen as too small and often overcrowded by non-residents. The harshest complaints surrounded service standards and lack of awareness that "so much can be done to attract visitors through closely attentive services at all times" (Rand Daily Mail, 1 Mar. 1944). Contributing to the poor quality of services often endured by tourists was the difficulties that hotels experienced in obtaining trained staff (Vynne, 1947; Walker, 1977). Food preparation standards and services and the "almost entire absence of good wholesome fruit from the average menu" were another theme of concern (Rand Daily Mail, 1 Mar. 1944). Accordingly, in order to facilitate the anticipated post-1945 boom in international tourism arrivals it was recommended hotels "must be overhauled and cleaned up" (Cape Times, 21 Nov. 1945).

The national Minister of Transport observed that in South Africa's major centres "our hotel accommodation, which is so limited that we cannot even accommodate the present trickle of visitors, while many South Africans are often unable to obtain hotel reservations" (South African Railways and Harbours, 1946: 328). The Chairman of the South African Tourist Corporation opined that tourists were "entitled to an honest standard of hotel accommodation" (Maggs, 1949: 17).

By this I mean that the man or woman who books in at an hotel charging $15 \mathrm{~s}$ a day cannot possibly expect the stylish accommodation nor the imposing array of food dishes appearing on the menu of $25 \mathrm{~s}$ or $30 \mathrm{~s}$ a day establishments nor the special services and little extras. But he is entitled to well-cooked fare, a clean tablecloth and napkin and an efficient table service. In addition, there is no reason why his room should not be thoroughly clean, airy and comfortable, and that adequate bathing and toilet facilities be available. (Maggs, 1949: 17)

Overall, the lack of quality accommodation services was conceded by national government representatives as a critical constraint for tourism development across the country (Maggs, 1949; University of Cape Town, 1949). This national challenge, however, needed to be set against the hard fact "that without the liquor side of the business, 90 per cent of the hotels in South Africa could not make ends meet" (Vynne, 1947: 15). Indeed, a 1949 survey on the state of hotels in South Africa confirmed that the standard of accommodation services was relatively low because the business of furnishing accommodation was far less profitable than the selling of liquor (University of Cape Town, 1949).

Several aspects of the contemporary development of Johannesburg's hotel industry are welldocumented (Rogerson, 2013b, 2013c, 2013d, 2013e, 2014). Nevertheless, the history of hotel development in the city remains largely unexplored. What is known, however, is that at the apex of the city's hotel economy were a small handful of luxury establishments, the genesis of which goes back to the early period of Johannesburg as a fast-growing settlement anchored upon the bounty of gold (Rosenthal, 1972; Hughes, 1983; Cole, 1988). The most famous and iconic establishment was the fashionable Carlton Hotel which opened in 1906. This luxury 
establishment could in many respects "be described as the forerunner of the modern Five-Star hotel" (Cole, 1988: 14). Built from the wealth of mining magnates the glamorous hotel "was an oasis of sheer luxury on the raw Highveld" with superior appointments and at the time was the largest building in South Africa (Benjamin, 1979: 10). With every item from the hotel specially imported the Carlton became "the rendezvous of discriminating people" (Rosenthal, 1972). It was reported that the "public marvelled at the building's inner-mechanics, all of the very latest - air conditioning and central heating, waterborne sewerage, its own supply of water and emergency power; even a central plug-in vacuum-cleaning service that had been invented in America only a couple of years before. Down in the basement there was a full-scale Turkish bath and massage establishment, with a marble swimming pool" (Benjamin, 1979: 10). Throughout the period of Johannesburg as an incipient tourism destination the quality accommodation and service standards of the Carlton were unrivalled (Fig. 2). The ground floor was occupied by several shops targeted to satisfy the requirements of the visitors, many of whom came from overseas who stayed at the hotel; the most colourful was Sieradzki's which sold ostrich plumes (Rosenthal, 1972; Hughes 1983). More than three decades after its initial opening marketing material proclaimed the Carlton to be "the hub of Africa" and offered to demonstrate to its discriminating clientele "what real hotel service means" (South African Railways and Harbours, 1939: 72). Although continually graced by visits of international celebrities, royalty and the rich and famous, the hotel's finest moment came in 1947 when the British Royal Family were guests of the Carlton while visiting Johannesburg (Rosenthal, 1972; Cole, 1988). 
Let Johannesburg's mighty

CARLTON show you

what real hotel service

means : ....

THE CARLTON'S friendly service to

1 its guests begins with the helpful.

ness of the porter who meets you at the

train or the commissionaire who greets you as you drive up to the door. From
then till we've seen you safely on your way, your comfort, your enjoyment and the best trained hotel staff in Africa. their hotel:-

THE INTELLIGENCE and helpfulness of its staff is just one item in guests, service of the Carlton to it guests, a standard of service you in the in this country. Here are some the things which the Cariton offers to

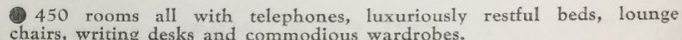

200 of these rooms also have private bathrooms and entrance hall

while 25 de luxe suites offer private sitting rooms as well.

- The Restaurant (service table d'hote or à la grande carte, the finest

The New and Greater Grill Room (inexpensive à la carte service).

The magnificent Palm Court.

The distinguished Ballroom.

Drawing Room and quiet writing room for residents.

Resplendently modern Hairdressing Saloons for Ladies and Gentlemen.

- The Men's Outfitting Shop.

- Theatre Booking Office.

- Travel Bureau.

THE CARLTON'S "ROOM ONLY" SYSTEM

WORKS OUT EXTREMELY REASONABLY

You pay 10s. 6d. up for your room (from 17s. 6d. with private bathroom and entrance

hall). You are then free to use the Restaurant and Grill Room as and when you like.

You do not have to pay for meals not taken in the hotel.

Fully detailed tarif "system is also available and the rates are surprisingly inexpensive Telegrams: "Caritonia".

THE

HUB OF

AFRICA

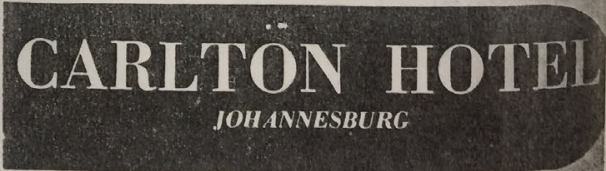

Figure 2: Carlton Hotel advertising 1939 (Source: South African Railways and Harbours, 1939).

The Carlton Hotel was an exceptional establishment in the Johannesburg hotelscape. Most Johannesburg hotels refracted the national problems in terms of limited quantity of international tourist facilities and existing establishments often exhibiting poor quality standards, especially of accommodation services, because of the economics of liquor domination. In 1944 the Chairman of the Johannesburg Publicity Association stated that the city's accommodation resources were "severely tried", a condition not assisted by the fact that the national government treated the hotel industry "as an outcast" (Rand Daily Mail, 27 October 1944). The poor levels of service offered in city hotels were flagged in speeches made by H.J. Crocker, the director of Johannesburg's publicity association. He stated in 1947 that "We must improve our manners, or, at least, learn to show a cheerful face to visitors" (cited in Vynne, 1947: 17). In 1950 widespread reports surfaced about conditions endured by tourists in the city's so-called 'best' hotels. From scathing comments made by both local and international visitors the following unpromising picture was painted.

Visitors complain that because accommodation is at a premium hoteliers say: 'Take it or leave it' and provide poor services.... They point to the insanitary state of public conveniences off the lounges of many of the hotels. The Johannesburg Health Department recently served notices on a number of city hotels in this connection... One hotel is notorious for its poor service of meals in rooms. Trays are sent with leaden cutlery and a pile up collection of foodstuffs - at an extra charge. Sheets, blankets and towels in a bad state of repair are used, the guests allege, 
and extra 'beds' crowded into rooms during peak seasons are stretchers - but no reduction in tariff is made. Other annoyances to guests are the itinerant vendors or charity collectors who are allowed within the lounges of a number of hotels. (Sunday Express, 9 April 1950)

The above descriptions confirm that by 1950 the critical infrastructural issues about hotel accommodation in Johannesburg remained unresolved.

\section{Conclusion}

Existing urban tourism research offers only limited glimpses into the emergence and challenges of localities in becoming tourist destinations. It is argued here that the adoption of an historical lens is useful to offer fresh insight on urban tourism. In the case of Johannesburg during the period 1920-1950 the city can be characterised at best as an incipient tourism destination. In building the tourism economy a number of challenges arose some of which were inseparable from the growth of tourism in South Africa as a whole and contingent for their resolution upon strategic interventions driven by national government. Major improvements in road, rail and air service accessibility served well the expansion of all forms of tourism in Johannesburg. Nevertheless, the role of local agency in developing the city tourism economy also must be acknowledged. From 1925 an important role was assumed by the Johannesburg Publicity Association in identifying and subsequently promoting the city's tourism assets for both domestic and international audiences. By 1950 the major shortcoming for tourism growth remained the unsatisfactory state of hotel accommodation services, which would only be comprehensively addressed during the 1960s by national government interventions. This said, from 1950 the tourism economy of Johannesburg would increasingly feel the impress of apartheid legislation which opened up a host of new challenges for urban tourism because of the requirements for separate and segregated facilities for people of different race groups.

Christian M. Rogerson, School of Tourism and Hospitality, University of Johannesburg, SouthAfrica (crogerson@uj.ac.za)

Jayne M. Rogerson, School of Tourism \& Hospitality, College of Business and Economics University of Johannesburg, Johannesburg, South Africa (jayner@uj.ac.za)

\section{Acknowledgements}

A summary version of this paper was presented at the International Geographical Union Commission on Tourism conference in Quebec City, August 2018.

\section{References}

Ashworth, G. J. \& Page, S. (2011) Urban tourism research: Recent progress and current paradoxes. Tourism Management, 32(1), pp. 1-15. DOI: 10.1016/j.tourman.2010.02.002

Benjamin, A. (1979) Lost Johannesburg. Johannesburg, Macmillan.

Bickford-Smith, V. (2009) Creating a city of the tourist imagination: The case of Cape Town, 'The Fairest Cape of all'. Urban Studies, 46(9), pp. 1763-1785. DOI: 10.1177/0042098009106013

Cape Times (1945) Cape Town.

Cirer-Costa, J.C. (2012) The beginnings of tourism in Majorca 1937-1914. Annals of Tourism Research, 39(4), pp. 1779-1796. DOI: 10.1016/j.annals.2012.06.004

City of Johannesburg (1951) The City of Johannesburg Official Guide. Cape Town, R. Beerman Publishers. 
Coca-Stefaniak, A., Morrison, A. M., Edwards, D., Graburn, N., Liu, C., Ooi- CS., et al. (2016) Editorial: Views from the editorial board of the International Journal of Tourism Cities. International Journal of Tourism Cities, 2(4), pp. 273-280. DOI: 10.1108/IJTC-10-2016-0041

Cocks, C. (2001) Doing the Town: The Rise of Urban Tourism in the United States, 1850-1915. Berkeley, University of California Press. DOI: 10.1525/california/9780520227460.001.0001

Cohen, E. \& Cohen, S. A. (2015) A mobilities approach to tourism from emerging world regions. Current Issues in Tourism, 18(1), pp. 11-43. DOI: 10.1080/13683500.2014.898617

Cole, M. (1988) Room In the Inn: The Story of Johannesburg Hotels. Johannesburg, Poplar Press.

Crocker, H. J. (1950) What's wrong with the hotel industry?. Commercial Opinion, 28 (December), p. 309 and p. 325.

Floor, B. C. (1985) The History of National Roads in South Africa. Cape Town, CTP.

Foster, J. (2003) 'Land of contrasts' or 'home we have always known': The SAR\&H and the imaginary geography of white South African nationhood, 1910-1930. Journal of Southern African Studies, 29(3), pp. 657-680. DOI: 10.1080/0305707032000094965

Gibbs, H. (1949) The tourist expects a comfortable hotel - does he always get it?. The Outspan, pp. 45, pp. 47 and pp. 97-98.

Hughes, L. (1983) Johannesburg: The Cosmopolitan City. Johannesburg, Delta.

Johannesburg Publicity Association (1931) Johannesburg: A Sunshine City Built on Gold. Johannesburg, Johannesburg Publicity Association and South African Railways and Harbours Administration.

Johannesburg Publicity Association (1945) South Africa's Tourist Industry. Johannesburg, Johannesburg Publicity Association.

Johannesburg Publicity Association (1947) Handbook for Visitors to Johannesburg. Johannesburg, Johannesburg Publicity Association.

Johannesburg Publicity Association (1948) Tourist Map of Johannesburg. Johannesburg, Johannesburg Publicity Association and South African Railways and Harbours Administration.

Johannesburg Publicity Association (1949) Handbook for Visitors to Johannesburg. Johannesburg, Johannesburg Publicity Association.

Kroonstad Times (1925) Kroonstad.

Law, C. M. (1992) Urban tourism and its contribution to economic regeneration. Urban Studies, 29, pp. 599-618. DOI: $10.1080 / 00420989220080581$

Law, C. M. (1993) Urban tourism: Attracting visitors to large cities. London: Mansell.

Maggs, E. O. C. (1949) What we expect our hotels to give the tourist. The Outspan, 46 (1178), pp. 17, 19 and 81. Municipal Magazine (1927) Johannesburg.

Norval, A. J. (1936) The Tourist Industry: A National and International Survey. London, Sir Isaac Pitman.

Pasquinelli, C. (2015) Urban tourism (s): Is there a case for a paradigm shift?. Cities Research Unit Working Papers No. 14. L' Aquila, Gran Sasso Science Institute.

Pasquinelli, C. \& Bellini, N. (2017) Global context, policies and practices in urban tourism: An introduction. In: Bellini, N. \& Pasquinelli, C. (eds.) Tourism in the city: Towards an integrative agenda on urban tourism. pp. 1-25. Cham, Springer. DOI: 10.1007/978-3-319-26877-4_1

Pirie, G. H. (2011) Elite exoticism: Sea-rail cruise tourism to South Africa, 1926-1939. African Historical Review, 43, pp. 73-99. DOI: 10.1080/17532523.2011.596621

Pirie, G. H. (2013). Automobile organizations driving tourism in pre-independence Africa. Journal of Tourism History, 5(1), pp. 73-91. DOI: 10.1080/1755182X.2012.758672

Rand Daily Mail (1936-1944) Johannesburg.

Rogerson, C. M. (2011) From liquor to leisure: The changing South African hotel industry 1928-1968. Urban Forum, 22, pp. 379-394. DOI: 10.1007/s12132-011-9126-9

Rogerson, C. M. \& Rogerson, J. M. (2017) City tourism in South Africa: Diversity and change. Tourism Review International, 21(2), pp. 193-211. DOI: 10.3727/154427217X14984977561745

Rogerson, J. M. (2013a) The changing accommodation landscape of Free State, 1936-2010: A case of tourism geography. African Journal for Physical Health Education, Recreation and Dance, 19(Supplement 2), pp. 86-104.

Rogerson, J. M. (2013b) Reconfiguring South Africa's hotel industry 1990-2010: Structure, segmentation and spatial transformation. Applied Geography, 36, pp. 59-68. DOI: 10.1016/j.apgeog.2012.06.004

Rogerson, J. M (2013c) Market segmentation and the changing budget hotel industry of urban South Africa, Urbani izziv, 24(2), pp. 112-123. DOI: 10.5379/urbani-izziv-en-2013-24-01-003

Rogerson, J. M. (2013d) Urban tourism and the changing structure of the hotel economy in South Africa, African Journal for Physical, Health Education, Recreation and Dance, 19(Supplement 2), pp. 39-54.

Rogerson, J. M. (2013e) The economic geography of South Africa's hotel industry 1990 to 2010. Urban Forum, 24(3), pp. 425-446. 
Rogerson, J. M. (2014) Hotel location in Africa's world class city: The case of Johannesburg, South Africa. Bulletin of Geography. Socio-Economic Series, 25, pp. 181-196. DOI: 10.2478/bog-2014-0038

Rogerson, J. M. (2016) Tourism geographies of the past: The uneven rise and fall of beach apartheid in South Africa. In Donaldson, R., Visser, G., Kemp, J. \& de Waal, J. (eds.), Celebrateacenturyofgeography: Proceedings of the Centenary Conference of the Society of South African Geographers, Stellenbosch: Society of South African Geographers, pp. 212-218.

Rogerson, J. M. (2017) 'Kicking sand in the face of apartheid': Segregated beaches in South Africa. Bulletin of Geography: Socio-Economic Series, 35, pp. 93-109. DOI: 10.1515/bog-2017-0007

Rosenthal, E. (1972) Meet me at the Carlton: The Story of Johannesburg's Old Carlton Hotel. Cape Town, H.B. Timmins.

Saarinen, J., Rogerson, C. M. \& Hall, C. M. (2017) Geographies of tourism development and planning. Tourism Geographies, 19(3), 307-317. DOI: 10.1080/14616688.2017.1307442

Saunders, C. \& Barben, T. (2007) The history of tourism. In R. George (ed.), Managing Tourism in South Africa. Cape Town, Oxford University Press, pp. 25-31.

South African Railways and Harbours (1919) Correspondence: Oversea Advertising Campaign. TES 3817 17/48. National Archives, Pretoria.

South African Railways and Harbours (1920a) Making South Africa known to settlers and tourists. South African Railways and Harbours Magazine, Jan., pp. 7-10.

South African Railways and Harbours (1920b) Correspondence: Overseas Advertising Scheme. Transvaal Archives Depot File MB 1/3/9.

South African Railways and Harbours (1927) Correspondence: Annual Conferences SA. Publicity Association SAS 877 G4/131/1.

South African Railways and Harbours (1932) Illustrated Guide to Hotels and Boarding Houses, 1932. Pretoria, Government Printer.

South African Railways and Harbours (1933) Johannesburg and the Reef. Johannesburg.

South African Railways and Harbours (1936) Illustrated Guide to Hotels and Boarding Houses, 1936. Pretoria, Government Printer.

South African Railways and Harbours (1939) Illustrated Guide to Hotels and Boarding Houses, 1939. Pretoria, Government Printer.

South African Railways and Harbours (1940) Illustrated Guide to Hotels, Boarding Houses and Farm Guest Houses, 1940. Pretoria, Government Printer.

South African Railways and Harbours (1945) Temporary airport at Palmietfontein. South African Railways and Harbours Magazine, May, pp. 134-135.

South African Railways and Harbours (1946) Establishment of interim board to control tourism development. South African Railways and Harbours Magazine, Nov., pp. 328-329.

South African Railways and Harbours (1950) South African Airways: A successful state enterprise. South African Railways and Harbours Magazine, June, pp. 159-163.

Sunday Express (1950) Johannesburg.

The Star (1939) Johannesburg.

The Union Publishing Agency (1924) The Illustrated Guide to South Africa 1924. Cape Town, Cape Times.

Timothy, D. J. (2012) Historical geographies of tourism. In: Wilson, J (ed.) The Routledge Handbook of Tourism Geographies, London, Routledge, pp. 157--162.

Towner, J. (1995) What is tourism's history?. Tourism Management, 16 (5), pp. 339-343. DOI: 10.1016/02615177(95)00032-J

Towner, J. \& Wall, G. (1991) History and tourism. Annals of Tourism Research, 18, pp. 71-84. DOI: 10.1016/0160-7383(91)90040-I

University of Cape Town (1949) Report on the Economy of the Tourist Hotel in South Africa. Pretoria, South African Tourist Corporation.

Van Eeden, J. (2011) Surveying the 'empty land' in selected South African postcards. International Journal of Tourism Research, 13, pp. 600-612. DOI: 10.1002/jtr.832

Van Eeden, J. (2012) Picturing the road: Automobility in selected South African postcards. Communicatio: South African Journal for Communication Theory and Research, 38(1), pp. 84-102. DOI: 10.1080/02500167.2011.627567

Van Eeden, J. (2014) South African Railways postcard collections, 1961 to 1984. South African Historical Journal, 66, pp. 79-103. DOI: 10.1080/02582473.2014.891645

Ward Price, G. (1927) A holiday centre. Municipal Magazine, Feb., p. 7.

Walker, G. S. (1977) The history of the South African hotel industry with special reference to the role of the Hotel Board. Unpublished dissertation, National Diploma in Hotel Management, The Hotel School, Johannesburg. 
Walton, J. K. (1997) Taking the history of tourism seriously. European History Quarterly, 27(4), pp. 563-571. DOI: $10.1177 / 026569149702700406$

Walton, J. K. (2005a) Introduction. In J.K. Walton (ed.), Histories of Tourism: Representation, Identity and Conflict. Clevedon, Channel View, pp. 1-18.

Walton, J. K. (2005b) Histories of tourism. In T. Jamal \& M. Robinson (eds.) The Sage Handbook of Tourism Studies, pp. 115-129. London, Sage.

Walton, J. K. (2009) Prospects in tourism history: Evolution, state of play and future developments. Tourism Management, 30, pp. 783-793. DOI: 10.1016/j.tourman.2009.05.010

Wolf, J. B. (1991) A grand tour: South Africa and American tourists between the wars. Journal of Popular Culture, 25, pp. 99-116. DOI: 10.1111/j.0022-3840.1991.2502_99.x

Zachariah, O. (1921) Travel in South Africa. Johannesburg, SAR\&H. 